\title{
Developing south-south cooperation: The case of Ethio-China economic relationship
}

Damtew, Rabia Yimam

Beijing Normal University, China (Rabiayimam2007@yahoo.com)

Tsegay, Samson Maekele $\bowtie$

Beijing Normal University, China (Samex221@gmail.com)

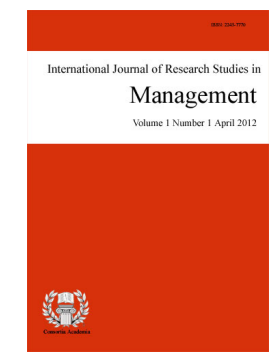

ISSN: 2243-7770

Online ISSN: 2243-7789

Received: 7 February 2017

\section{Abstract}

Through secondary data and open-ended questionnaire, the study examines the Ethio-China economic cooperation by focusing on trade and investment from the Ethiopian side. Drawing on the concept of South-South Cooperation, the paper argues that despite the socio-economic and technological variation between Ethiopia and China, both countries benefit from their economic cooperation. To understand the issue, the study focused on two main issues: the current situation of Ethio-China economic cooperation, and possible challenges the cooperation could face. The various agreements on technological cooperation between the two governments show that the Ethio-China cooperation is strongly substantiated by the two governments' political relationship. The study also indicated that despite in Ethiopia trade balance favors China and most of the investment projects are solely owned by Chinese investors, Ethiopia is still benefiting from FDI, transfer of knowledge, as well as different Chinese loan and aids. The result from gravity model shows that Chinese population and distance between the two countries affect trade between Ethiopia and china negatively, whereas both indicators have no significant effect on trade facilitation. Without generalization, the research to some extent can be considered as explanatory to other South-South Cooperation particularly in connection with China and other developing countries that share similar conditions as Ethiopia.

Keywords: south-south cooperation; Ethiopia; China; trade; investment 


\section{Developing south-south cooperation: The case of Ethio-China economic relationship}

\section{Introduction}

South-South cooperation is characterized by multiplicity of actors. While the economic relationship among China, India, Brazil and South Africa has attracted attention, there are many other cooperation efforts between different developing countries. This study focuses on the case of Ethio-China economic relationship.

China's emergence as the second largest economy of the world and most importantly an alternative economic partner enabled the country to play an important and influential role in the global economy. This situation has also benefited many developing countries over the past decade. The country is working closely with many developing countries and international organizations to promote South-South Cooperation. South-South Cooperation is a development cooperation focused on the exchange of resources, technology, and knowledge for sustainable development and eradicating poverty within developing countries. With the commitment to achieve its vision of becoming a middle income country by 2025, Ethiopia is one of the countries that are closely working with China.

Despite the fact that Ethiopia and China have imperial backgrounds, formal diplomatic relations started on November 24, 1970 (Geda, 2008), four years before the overthrow of Emperor Haile Selassie by the left-wing military junta, led by Colonel Mengistu Hailemariam. For the first two decades, China maintained a modesty relationship with Ethiopia. However, after the fall of Colonel Mengistu in 1991, Ethio-China relationship began to surge and China became one of the top economic partners of Ethiopia balancing the economic ties of Ethiopia with Western countries.

In 2009, the volume of trade between the two countries amounted to about US $\$ 1.5$ billion (Ministry of Foreign Affairs, 2010). Since the start of the Comprehensive Cooperative Partnership in 2003, Ethio-China relations have developed rapidly in which the countries have signed a series of agreements on socio-economic, political and technical cooperation. As a result, between 2003 and 2013, the yearly volume of bilateral trade between Ethiopia and China increased by more than 13 times (Ghebreyesus \& Yi, 2014). However, there are not adequate published works exploring the Ethio-China economic relationship. The few existing ones are mainly opinions, rather than research papers.

Through primary and secondary data, the study analyzes how Ethiopia is engaging in trade and investment with China. It asks the main research question, how Ethiopia is engaging with China in South-South Cooperation? The following two sub questions are focused: 1) what is the condition of Ethio-China economic cooperation, and 2) what are the challenges of Ethio-China economic cooperation?

Answering the above research questions enables the study to enhance the Ethio-China economic cooperation. It makes an input in filling the lack of research and shapes the policy in practice. Although this research may not be generalizable, to some extent it can be considered as explanatory to other cooperation within developing countries, especially countries with similar conditions as Ethiopia and China. In addition, the study extends the literature on South-South Cooperation, and it can be used as a base for further studies.

\section{Overview of Related Literature}

\subsection{South-South Cooperation}

South-South Cooperation is a broad term with multiple definitions and perspectives from different dimensions. Most of the definitions concur with the idea of the United Nations Population Fund (UNFPA) (2011, 
Developing south-south cooperation: The case of Ethio-China economic relationship

p. 2) that South-South Cooperation is "a means of development by an exchange of knowledge, experience, technology and information and capacity development between and among developing countries". South-South Cooperation is often established within Southern (developing) countries of the world regardless of their geographical positions (Ugwuja, Ubaku, Obiakor, \& Ibekilo, 2014). It covers both the southern and northern hemispheres. South-South Cooperation involves two or more developing countries on a bilateral or regional basis (Ugwuja et al., 2014). In such situations, Southern nations share knowledge, skills, expertise and resources to meet their development goals through rigorous efforts in a win-win condition. Hence, South-South Cooperation is broad and multidimensional framework for collaboration in the political, economic, social, cultural, environmental and technical domains.

Within the economic sector, South-South Cooperation involves any action or policy by a developing country that privileges economic transactions with one or more developing countries (Agarwal, 2013). In this sense, South-South Cooperation, including technical and economic cooperation, is a means of promoting effective and sustainable development by sharing best practices, resources and technical expertise among developing countries. The cooperating countries can gain various benefits such as lower import duty and sharing of expertise. In this way, effective South-South economic cooperation requires significant transaction in the fields of trade, investment and financial flows.

\subsection{Approach to South-South Cooperation}

South-South Cooperation consists multiple ranges of collaborations among developing countries (Rosseel, De Corte, Blommaert, \& Verniers, 2009). Due to its distinctive aim for mutual development of developing countries, various theories could be adapted to understand the nature of South-South Cooperation. However, the theoretical framework or approach of this study is set based on the questions it focuses, to offer basic foundations and understanding on South-South Cooperation with regard to trade and investment. It draws on the notion of Japan International Cooperation Agency (2005) on South-South Cooperation. The agency states that South-South Cooperation is "mutual cooperation aimed at fostering self-sustaining development, involving deepening relations among developing countries while conducting technical and economic cooperation" (p.1). Despite the fact that this definition is complex and with multiple variables, this study incorporates variables that are pertinent to trade and investment as its main focus. Therefore, different variables or concepts especially technical cooperation, capacity development, FDI and trade flow are used to guide the study and analyze the issue under investigation.

South-South Cooperation goes beyond aid to promote self-sufficiency among developing countries. Hence, Technical Cooperation for Developing Countries (TCDC) is essentially a process of individual or collective development within two or more developing countries through cooperative exchanges of knowledge, skills, resources and technical know-how (United Nations, 2003). In TCDC, governments initiate, organize and manage different activities while involving different governmental and non-governmental institutions and individuals. As a result of its multidimensional capacity, TCDC include all sectors and all kinds of technical cooperation activities among developing countries. This includes bilateral cooperation between two developing countries like Ethiopia and China.

Capacity development is the process by which individuals or institutions increase their ability to perform core functions effectively and efficiently to achieve their objectives; it is the strengthening of one's capacity to understand and sustainably deal with development issues (Babu \& Sengupta, 2006). South-South cooperation tends to strongly focus on capacity development since technical cooperation is embedded as a tool for mutual learning. This includes facilitating the exchange and sharing of development solutions, providing practical guidance and support to ensure high quality knowledge sharing such as short and long-term exchanges, learning routes, study tours and training. Moreover, as Rosseel et al (2009) stated, developing countries are increasingly becoming home for Foreign Direct Investment (FDI) flows originating from other developing countries. This shows that South-South trade and investment contributes for socio-economic development by providing different 
opportunities at grassroot and national levels such as job opportunities in the labor intensive Southern investments, and transfer of resources and networks.

\subsection{South-South Trade and Investment}

Recent developments in South-South Cooperation have taken the form of trade and investment, foreign direct investment, technology transfers, and other forms of exchanges for sharing different resources and experts. As a result of the debt crisis during the 1980s and the disagreement on the General Agreement on Tariffs and Trade (GATT) Uruguay Round ('86-'93), developing countries started to look for internal means of cooperation, and this was made possible with the emergence of new Southern powers like China and India (Vaes \& Huyse, 2013). These countries brought hope to developing countries and they became a driving force for the rediscovery of South-South trade and cooperation both internally and externally which was dominated by the North.

The rise of China and other emerging powers such as India, Brazil, South-Africa and other Southern states has intensified trade and investment within the South. For instance, BRICS (Brazil, Russia, India, China and South Africa) in which four out of the five countries are Southern countries cover $45 \%$ of world population, $25 \%$ of the global GDP and 15\% of world trade (Bilal, 2012). The countries are also the largest trading partner for Africa. BRICS is one of the strongest economic alliances which works to transform the economic cooperation of nation-states mainly developing countries. Besides, four member of BRICS belong to the top ten economies of the world. Therefore, the South-South trade and investment which is rooted on the principle of non-interference advocates for extensive trade and cooperation as well as for a better and just economic order of the world (Vaes \& Huyse, 2013).

The respect of Southern nations for national sovereignty and the focus to mutual cooperation greatly foster national ownership of the cooperation's objectives both in trade and investment. Besides, the experiences of the newly emerging powers like China in overcoming specific development challenges can be an advantage in responding to similar challenges in other developing countries like Ethiopia. Moreover, the economic development of countries without harming the economic level or position of their partners is significant (Sen, 2003). Therefore, this could be seen as a positive dimension to trade and investment which is based on opportunity, solidarity as well as mutual benefit and recognition of reciprocity, rather than fear of exploitation which is a common phenomena in trade and investment agreement with the North.

There is a widespread criticism on South-South Cooperation especially from the North. Northern states argue that South-South Cooperation (especially trade and investment) with some of the emerging countries such as the BICS (BRICS without Russia) is not equally based. The emerging countries exploit other developing countries such as sub-Saharan countries. This argument is based on the idea that the emerging countries' firms including Chinese firms bring thousands of workers from their home instead of hiring local people from Africa; and they dominate the local business and market with their cheap and low quality goods especially with the massive import of cheap consumer products (Vaes \& Huyse, 2013).

Generally, South-South Cooperation is taking a more coherent and integrated approach to development cooperation by including trade and investments. For instance, $90 \%$ of African exports benefit from unilateral Chinese and Indian tariff exemption. However, there is an issue of blending aid with commercial instruments which sometimes could lead to distortion of market and unfair competition (Vaes \& Huyse, 2013).

\subsection{Opportunities and challenges of South-South Cooperation}

Development support through South-South Cooperation could be more cost effective than North-South Cooperation, since Southern countries have similar societies and economies, compared to Northern countries. Since countries within South-South cooperation share similar developmental challenges, their technical cooperation can provide practices and solutions that are highly adaptable to local economic and social conditions (Task Team on South-South Cooperation, 2011). Therefore, they can setup innovative approaches, methods and 
Developing south-south cooperation: The case of Ethio-China economic relationship

techniques that are particularly adapted to local needs and thus build upon existing modalities of technical cooperation which have proven to be useful (United Nations, 2003). According to the United Nations (2012), South-South Cooperation is a powerful tool to:

$>\quad$ Transfer of knowledge and development solutions

$>\quad$ Increase opportunities and maximize mutual benefits within developing countries

$>$ Develop partnerships by enabling harmonization of policies, legal frameworks and regulations

$>$ Strengthen Southern perspectives and actions in global development agendas by convening and connecting a wide variety of stakeholders.

Through South-South Cooperation, developing countries are able to engage in the global development architecture, rather than becoming recipients of aid (OECD, 2011). South-South Cooperation especially within economic and trade cooperation offers opportunities to pull economic, human, institutional, technological and infrastructural resources and networks of the participating countries (Rosseel et al., 2009). It also enables countries to share different achievements and lessons so that others can learn how to overcome similar problems without trial and error while reducing costs and enhancing efficiency (Dargin, 2013).

According to OECD (2011), South-South Cooperation faces several challenges mainly related to institutional and technical capacities of Southern countries. Some of the challenges are connected to very limited and unequivocally compelling data which affects the quality of information to ensure transparency and improve quality and results of the cooperation. Moreover, there is a problem in the alignment of South-South Cooperation systems and developments to countries' diversified national policies and systems. This is due to the priority that each participant makes for its national interests. Hence, the narrow conception of national interest affects the effectiveness of South-South relations.

\section{Methodology}

The research is mixed approach with a case study design. As this study focuses on developing South-South Cooperation (SSC) with the focus on the case of Ethio-China economic relationship, mixed research methodology enables to explore the conditions and understand the situation by integrating both quantitative and qualitative methods (McNabb, 2008). The study used a case study design to enable the readers of the research to find applications to other Southern countries without attempting broad or even limited generalization.

\subsection{Sample and Sampling Procedure}

25 participants comprising government officials and ordinary citizens were used as a sample for collecting qualitative data. These participants were selected by purposive sampling in order to represent a broader group of cases for the study (Wiersma \& Jurs, 2004). The research participants were give complete information on the study, participants' rights and their consent to participate in the study was obtained before filling the questionnaire. Their participation to the study was voluntary, and the response that participants give is kept confidential. Pseudonyms were used to protect the identity of the participants. The researchers also believe that their familiarity and relationship with some of the participants enabled to get honest and unreserved responses.

\subsection{Data collection}

Document review and questionnaire were used to collect data for the study. To investigate how Ethiopia engages with China on South-South Cooperation, qualitative data was collected through open-ended questionnaire. A questionnaire consisting three demographic and seven open-ended questions was developed to solicit information regarding South-South Cooperation on current conditions, lessons shared and challenges faced between the countries with a special focus in trade and investment. The respondents returned written responses either in soft or hard copy through email or personal delivery. An open ended questionnaire was used because open-ended response allows to get information which could enable us to understand the situation as perceived by the participants (Bryman, 2008; Labuschagne, 2003). 
Moreover, related and relevant documents were reviewed from different sources to explore the Ethio-China economic relationship. This study mainly reviewed information related to trade flow, FDI, capacity development, trade, GDP and others especially related to trade and investment issues between Ethiopia and China. Hence, secondary data from the World Bank and World Trade Organization websites (World Bank, 2014a, 2014b) and other governmental documents were used. The study especially used fifteen years (2000-2014) data from the World Bank for the empirical analysis through Gravity Model with linear regression.

\subsection{Data Analysis}

The study employed descriptive and statistical analysis to analyze the data collected through document review and questionnaire. Gravity model with linear regression was used to analyze part of the secondary data. The outcome of the questionnaire was discussed using descriptive analysis in which a structural skeleton is established to provide meaningful interpretation and analysis (McNabb, 2008). Finally, the data was rewritten with the researcher's interpretation and conclusion with a reference to theoretical perspectives and empirical studies.

The gravity model is widely used as a benchmark to estimate bilateral trade flow between countries based on the supply of the exporter country, the demand of the importer country and trade barriers (Caporale, Sova \& Sova, 2015). First used in 1962 by Tinbergen, and later by Pöyhönen (1963) to explain bilateral trade flow, the model takes national income of two countries, transport cost (transaction cost) and regional agreement as the main determinants of trade (Deardorff, 1998). The importance of the gravity model initiates from the fact that it is used to understand bilateral trade flows and the welfare effects of economic integration. In its simplest form, the gravity model explains the amount of trade flow between two countries as an increasing function of their sizes and a decreasing function of transportation cost (distance) between them. This means that it explains trade flow on the basis of the physical characteristics of the importing and exporting countries and the existence of any impediments to trade. Therefore, a so-called 'gravity equation' can be developed as a reduced form equation that is simply derived from export (or import) supply and demand functions, representing the equilibrium of bilateral export supply to export demand. Simple form of gravity equation can be written as:

$$
x_{\mathrm{ce}}=a_{0}+\mathrm{a}_{1} y_{c}+a_{2} y_{\mathrm{e}}+a 3 n_{c}+a 4 n_{e}+a 5 d_{\mathrm{ce}}+e_{c e}
$$

Where $x c e$ represents the exports from country $C$ to country E; $y_{C}$ is the income of the exporting country and can be thought as the production capacity of the exporting country (i.e. a proxy for the capital stock of the exporting country), $y E$ is the income of the importing country and acts as a proxy for the consumption capacity of the importing country. While $n$ represents the population of countries $C$ and $E$ respectively and proxies the size of the economy; and $d_{c e}$ is the physical distance between countries $c$ and $e$.

\section{Findings and Analysis}

\subsection{Ethio-China Economic Cooperation}

The Ethio-China economic cooperation is historical with about half a century years old. Within this time, various bilateral agreements have been signed between Ethiopia and China. As the World Bank (2012) stated, the economic cooperation between the two countries is mainly supported by strong political facilitation from both governments. According to the Ministry of Foreign Affairs of China (2006), these agreements include:

$>$ Ethio-China Agreement Concerning the Encouragement and Reciprocal Protection of Investments ( 1998);

$>$ Ethio-China Agreement for Economic and Technological Cooperation (1971, 1988, 2002);

$>$ Ethio-China Agreement for Trade, Economic and Technological Cooperation (1996);

Ethio-China Agreement for Mutual Promotion and Protection of Investment (1988);

Ethio-China Trade Protocol (1984,1986,1988); 
$>$ Ethio-China Trade Agreement (1971, 1976).

These agreements have enabled to increase trade and investment between the two countries. Moreover, this transformed into comprehensive and strategic partnership with the establishment of the Forum on China-Africa Cooperation (FOCAC) in 2000, in which Ethiopia hosted and co-chaired the second Ministerial meeting of FOCAC in 2003. This shows a very strong connection between Ethiopia and China. Furthermore, the direct flight of Ethiopian airline to Chinese Cities of Beijing and Guangzhou has increased the connection between the two countries and the role Ethiopia plays in the relationship between China and other African countries (Wei, 2010).

\subsection{Increasing Trade}

Both Ethiopia and China are increasing their horizons through different socio-economic and political cooperation in the world. Considering the emergence of China as a global power and the notion of South-South Cooperation, the bilateral trade relationship between Ethiopia and China is increasing from time to time. The data from Ethiopian Chamber of Commerce and Sectorial Associations (ECCSA) (2012) shows that both import and export between Ethiopia and China increased from 2004 to 2010 tremendously. As illustrated in table 1, within seven years, the export level between Ethiopia and China increased from USD 14,877,760 to 228,162,023; while the amount of imports rose from USD 353,107,130 to 1,968,907,298. Moreover, the table indicates that the total trade turnover surged from around 353 million dollar in 2004 to more than 1.6 billion dollar in 2011, showing a growth rate of $376 \%$.

\section{Table 1}

Comparison of export, import, trade balance, total trade turn over and annual growth rate (ECCSA, 2012)

\begin{tabular}{llllllll}
\hline Year & $\begin{array}{c}\text { Export } \\
\text { (USD) }\end{array}$ & GR $(\%)$ & Import (USD) & GR $(\%)$ & $\begin{array}{r}\text { Trade Balance } \\
(\text { USD) }\end{array}$ & TTTO (USD) & $\begin{array}{c}\text { GR of } \\
\text { TTTO }(\%)\end{array}$ \\
\hline 2004 & $14,877,760$ & - & $388,229,370$ & - & - & $353,107,130$ & - \\
2005 & $78,930,605$ & 431 & $473,132,111$ & 40 & $-323,351,609$ & $552,062,716$ & 56 \\
2006 & $71,687,707$ & -9 & $589,144,981$ & 25 & $-394,201,507$ & $660,832,689$ & 20 \\
2007 & $67,639,545$ & -6 & $910,205,011$ & 54 & $-517,457,274$ & $977,844,556$ & 48 \\
2008 & $80,619,539$ & 19 & $1,424,162,891$ & 56 & $-842,565,467$ & $1,504,782,430$ & 54 \\
2009 & $211,121,369$ & 162 & $1,599,359,401$ & 12 & $-1,343,543,353$ & $1,810,480,770$ & 20 \\
2010 & $228,162,023$ & 8 & $1,740,745,274$ & 9 & $-388,238,031$ & $1,968,907,298$ & 9 \\
2011 & $280,195,081$ & 23 & $1,400,195,045$ & -20 & $-1,512,583,251$ & $1,680,390,126$ & -15 \\
\hline
\end{tabular}

Note. GR=Growth Rate; TTTO= Total Trade Turnover

Considering the low industrial and technological condition of Ethiopia, most of the exports of the country to China are agricultural and semi-processed goods. Conversely, Ethiopia imports high-tech commodities including heavy machinery and electronics from China as indicated in Table 2.

Table 2

Major exported goods from Ethiopia to China and imported goods from China (ECCSA, 2012)

\begin{tabular}{ll}
\hline \multicolumn{1}{c}{ Major Exported Products to China } & \multicolumn{1}{c}{ Major Imported Products from China } \\
\hline Sesame seed and other oil seeds & Different types of machineries \\
Hides and skins & Household and consumable goods \\
Tantalum, niobium and other ores & Vehicles and spares \\
Natural gum & Yarn and woven fabrics \\
Coffee & Electronic appliances \\
\hline
\end{tabular}

The economic situation in general and trade relationship between the two countries in particular is increasing significantly. According to the World Bank (2014), Ethiopia is growing to be the major trading partner of China with a total export of USD 533 million and imports of over USD 5 billion. As Ethiopia's fourth major 
export destination, and top import origin country, in 2014 China shared $9.41 \%$ and $26.51 \%$ of Ethiopia's overall export and import amount respectively. Accordingly, Ethiopia was able to create many jobs and other economic opportunities for its citizens. This concurs with the idea that South-South Cooperation gives Southern countries an opportunity to develop their market and experience to enjoy a period of rapid economic growth and development (Assefa, Bienen, \& Ciuriak, 2013).

South-South Cooperation is meant to strengthen mutual benefits (United Nations, 2012). However, considering the various socio-economic developments of Southern countries, it is naive to expect an equal trade and investment distribution within the economic cooperation of two developing countries. In general, in 2014, Ethiopia recorded a negative trade balance of $\$ 10.8$ billion, exporting $\$ 5.56$ billion and importing $\$ 16.4$ billion (The Observatory of economic complexity, 2014). As indicated in the following figure (Figure 2), globally Ethiopia resulted a trade deficit in the entire three years. Moreover, the trend is increasing from 2013 to 2015.

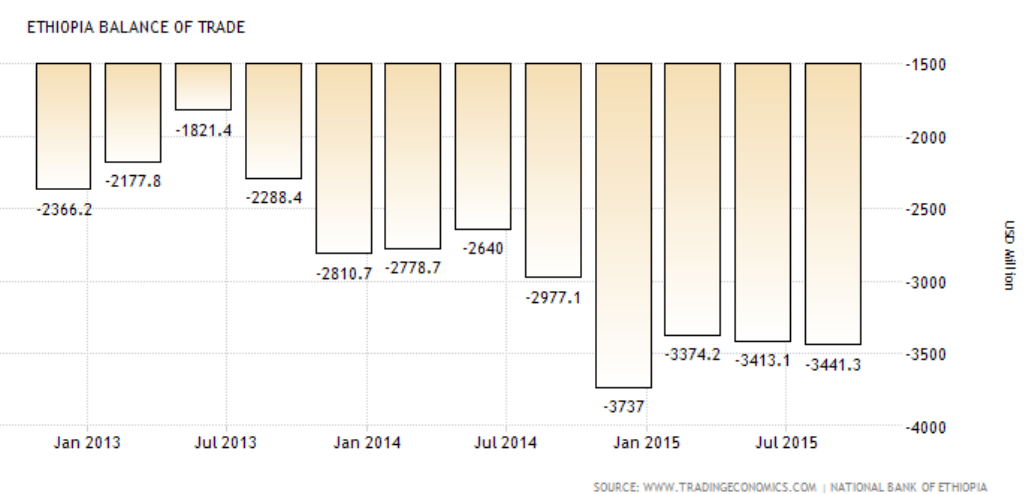

Figure 1. Ethiopia balance of trade over 2013 and 2015 (Source: Trading Economics).

Conversely, the situation is much better in China as the country has been showing a record of consistent trade surplus since 1995 which surged 10 times in the later decade especially from 2004 to 2009 (Trading Economics, 2016). As seen in Figure 3 below, despite the fluctuations, China's trade balance is still positive.

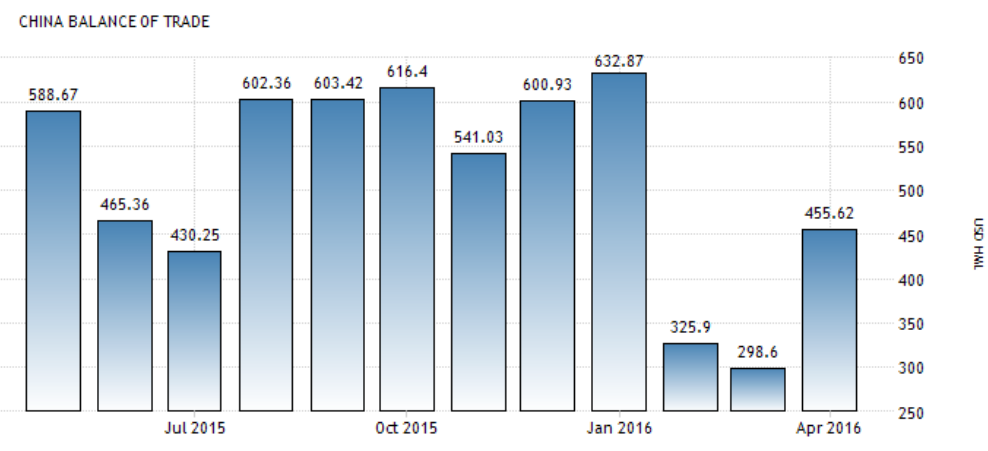

Figure 2. China balance of trade over 2015 and 2016 (Source: Trading Economics).

The trade balance between Ethiopia and China is highly inclined in favor of China (ECCSA, 2012). From 2004 to 2011, Ethiopia imported worth of USD 8.5 billion goods in eight years. Nevertheless, Ethiopia exported USD 1.3 billion worth of goods and this accounted for about $13 \%$ of its import from China. The trade imbalance is then creating a vast trade deficit for Ethiopia and this is due to the fact that Ethiopia exports primary non-processed agrarian products while importing intermediate and manufactured goods such as machineries and vehicles.

\subsection{Manufacturing-Dominated Investment}

According to the Forum on China-Africa Cooperation, Chinese economic and trade cooperation with Africa is constantly pushing African economic growth which is mainly reflected in the construction of infrastructure 
Developing south-south cooperation: The case of Ethio-China economic relationship

projects, industrial development and human resources (Wei, 2010). This is not different in the situation of Ethiopia in which both the Chinese government and its citizens are investing heavily in Ethiopia.

Chinese investors have invested millions of dollars in Ethiopia in different sectors. Chinese investors have owned about 938 projects over fifteen years, from 1998 to 2012. These projects account for about ETB. 42 Billion (USD 2 Billion @ 21ETB/\$) creating about 67, 672 and 79, 883 permanent and temporary employments respectively (ECCSA, 2012). The ECCSA (2012) further stated that more than half (57\%) of the 938 investment projects are in the manufacturing sector followed by Real Estate, machinery and equipment rental and consultancy Service (15\%), and construction contracting including Water Well Drilling (11\%). However, very low amount is invested in basic social services such as education (1\%) and health (2\%).

As indicated above, Chinese investments are creating thousands of job for Ethiopians. For example, the Huajian International Shoe City is one the world's biggest women's shoes manufacturers investing in Ethiopia. The company alone employs 4,000 workers in Ethiopia (FOCAC, 2011; Lei, 2015; Zizhu, 2015).

Most of Chinese investments in Ethiopia are private owned. According to the World Bank, (2012), Chinese private enterprises own $69 \%$ of the firms in Ethiopia. $15 \%$ are owned by Chinese-Ethiopian private joint venture while the state owns $13 \%$. Even within the joint venture enterprises, Chinese investors usually own the largest percentage ranging from 60 to 80 percent of the enterprises. This divided the perception of respondents of this study. Some stated that the Ethio-China cooperation has a strong connection even at lower levels which could make the economic transaction sustainable. Whereas other respondents argued that large ownership of the enterprises by Chinese investors is decreasing the number of Ethiopian potential investors which could not compete with the Chinese capital and technological power.

China's Foreign Direct Investment (FDI) in Ethiopia reached USD 58.5 million in 2010 from almost non-existent in 2004, which made the country one of the top FDI destination of China in Africa (Addis Fortune, 2013; Schreurs, 2013; World Bank, 2012). Chinese investment in Ethiopia shows the commitment of the Ethio-China cooperation. Referring to this, many respondents said that Ethio-China cooperation is good example of South-South Cooperation because it is driven by the countries' overall struggle to boost their socio-economic and political development. Clarifying this argument, Simon explained:

\begin{abstract}
To my knowledge and understanding, the relationship between Ethiopia and China is a strategic partnership and cooperation. This relationship is a comprehensive cooperation in economic, social, political and cultural issues. Among these relations, I think the dominant one is economical cooperation which is fundamentally based on mutual goals and benefits. As we know Ethiopia has political stability, visionary government and very well policy; the country is rich in natural and human resources and strategic geographical location. Hence, Ethiopia has become a point of attraction for economic development by various countries particularly China. Ethiopia also highly values Chinese cooperation and Chinese investment which are politically free and without hegemonic preconditions.
\end{abstract}

In general, it could be argued that Chinese investment is bringing a significant change even at the grassroots level by giving employment opportunities to ordinary citizens. This is a positive effect of South-South Cooperation when seen against the Western countries principle of debt and assistance which mainly cripples developing countries, instead of promoting sustainable growth or development. It is in this line that the respondents noted that there are no political preconditions in the Ethio-China trade and investment cooperation. For instance, a respondent, Haile argued that China's "business is business" approach is welcomed in comparison to Western aid providers that often attach a political demand to their contributions. Moreover, Chinese investment is supplemented with generous loans, development of infrastructure, debt cancellation and political non-interference. In such case, that OECD (2011) argued that developing countries through South-South Cooperation can move beyond their traditional role as recipients and contribute to mutual socio-economic development. 


\subsection{Empirical Analysis}

The researchers used three variables (income of China and Ethiopia, Population of China and Ethiopia, and distance between the two countries) to explain trade integration between Ethiopia and China. Gravity model with linear regression is used with export from China to Ethiopia as dependent variable. The analysis is based on the World Bank Data from 2000 to 2014. Accordingly, the following table shows the result of the gravity model with linear regression.

Table 3

Trade integration between Ethiopia and China as explained in gravity model with linear regression

\begin{tabular}{lcccc}
\hline \multicolumn{1}{c}{ Variables } & Coefficient & Standard Error & \multicolumn{2}{c}{ Confidence Interval (5\%) } \\
\hline Constant & 0.96 & 0.0021 & 0.67 & 1.04 \\
China Income & 0.037 & 0.00076 & 0.009 & 0.059 \\
Ethiopia Income & 0.0643 & 0.0014 & 0.0031 & 0.086 \\
Population China & -0.0079 & 0.00006 & -0.002 & -0.0096 \\
Population Ethiopia & 0.097 & 0.00761 & 0.051 & 0.153 \\
Distance & -0.004 & 0.0052 & -0.0018 & -0.0064 \\
\hline Note. Dependent Variable: Export from China to Ethiopia. & Adjusted R2 $=62.3 \%$. & &
\end{tabular}

Adjusted $\mathrm{R}^{2}$ of independent variables in the model explained $62.3 \%$ of the dependent variable that is Export from China to Ethiopia. As shown in the table, Chinese population and distance between two countries negatively affect the trade between china and Ethiopia at 5\% level of significance. But the two indicators do not significantly affect the trade facilitation. The income of China and Ethiopia as well as the population of Ethiopia showed a positive effect at $5 \%$ level of significance.

\subsection{The Path to Win-Win Situation}

South-South Cooperation in general, and trade and investment in particular aims for equal cooperation of Southern countries fostering to be owners of their policy and cooperation objectives (Vaes \& Huyse, 2013). As explained previously, trade balance between Ethiopia and China favors China creating trade deficit for Ethiopia. That could be the reason that some of the respondents in the questionnaire explained that the Ethio-China cooperation is mainly beneficial to China. Related to this issue, Omer, stated:

The economic relationship between Ethiopia and China has more benefited Chinese than Ethiopia. This is because China has a potential to supply large amount of readymade products to Ethiopia while Ethiopia largely depends on the supply of small amount agricultural products which is not consistent throughout the year. In addition, the import of low quality good affects Ethiopia.

Conversely, Almaz described the Ethio-China cooperation as a win-win situation.

The economic relationship between Ethiopia and China is beneficial to both countries. Chinese involvement in Ethiopia has been boosted growth and promoted exports. The cooperation with China is providing foreign aid and facilitating imports of cheap consumer goods and extensive investments to Ethiopia. On the other hand, Ethiopia is serving as a potential source of raw materials and market place for Chinese products.

The arguments of Omer and Almaz seem logical considering the socio-economic and political situation of Ethiopia including its large number of population on one side and the emergence of China as major global power on the other. It could be argued that this situation is adding fuel to the overall principle of South-South cooperation and the target of the two countries for the coming decade. The vision of Ethiopia to become a middle income country by 2025, and the journey of China to be placed at the top of the world are both significant drives. In agreement with Omer's statement, Simon explained: 
Developing south-south cooperation: The case of Ethio-China economic relationship

I think, the economic relationship between Ethiopia and China is mainly driven by China, with the country providing large amounts of foreign aid (often tied to infrastructure projects undertaken by Chinese firms); there is growing Chinese investment in the Ethiopian economy with imports of various commodities including cheap consumer goods dominating Ethiopia's market and benefiting mainly Chinese investors. The Chinese appear to be interested in Ethiopia primarily as a source of raw materials, potentially oil and food, and as a market for Chinese exports that will expand as Ethiopia's economic growth continues.

Despite the feeling that China is benefiting and more dominating the cooperation, Simon acknowledged that Ethio-China cooperation is also benefiting Ethiopia in one or another means. Simon further stated, "For Ethiopia, Chinese involvement is stimulating economic growth and promoting Ethiopia's exports to other countries".

The above excerpts explore the complex issue of South-South Cooperation in countries with big economic gap like Ethiopia and China. However, looking at the overall development of the countries and their consistent economic history for the last two decades, China had been enjoying a positive trade balance even with big and advanced countries like the USA, the UK and India (Trading Economics, 2016).

It could be argue that Ethio-China agreement on trade and economic cooperation goes beyond competition or domination of the market. This is clearly manifested in the Ethio-China agreement on trade and economic cooperation signed in November 2011 by Jiang Yaoping, Chinese Vice Minister of Commerce, and Sufian Ahmed, Ethiopian Minister of Finance and Economic Development, and Wondirad Mandefro, Ethiopian State Minister of Agriculture (People's Daily Online, 2011). According to the agreement, China provided a loan of 100 million U.S. dollar to finance: the Addis Ababa Deep Well Water Supply Project, and donated 90 vehicles comprising 65 automobiles and 25 buses to Ethiopia. This is a good example and an indication for the argument that the surplus China gains from Ethiopia usually comes around in one or another means. It is from this spirit that Minister Sufian Ahmed stated,

The relations between Ethiopia and China have been strengthened day by day, particularly the cooperation between the two countries has significantly increased in the last few years in areas of trade, investment and infrastructural development.

Not different from the above excerpt, a respondent, Girma stated that Ethio-China cooperation is a win-win situation. Clarrifying the situation, Girma said:

Encouraged by Ethiopian government policy for foreign investment, China's investment in Ethiopia is earning the country cheap raw materials and man power, and a market for its goods. However, China is also implementing various projects to help Ethiopia. For instance, the $\$ 475$ million urban rail project - funded by China - is one good example of Chinese Government's huge role in Ethiopia's infrastructure development. The world's most populous nation has also built dams, roads, and factories in Ethiopia, and even gifted Addis Ababa the African Union headquarter, which costed $\$ 200$ million.

All the above arguments show that various trade and investment agreements are enabling both countries to move forward with peace and solidarity.

Moreover, china is promoting the human capacity of Ethiopia through different means. Every year hundreds of Ethiopians are offered the Chinese Government Scholarship and other full or partial scholarships to study in China. Moreover, China cooperates with Ethiopia in building schools, and developing the human and material resources of Ethiopian education institutions. Chinese enterprises give high attention in developing the capacity of local employees. When we take Huajian International Shoe City, the company has about 4000 workers starting from ordinary staff to higher management. The management of the company state that they offer each employee a chance to be trained and promoted (Lei, 2015; Zizhu, 2015). Such capacity development is also done at 
governmental level in which many Chinese professional come to Ethiopia to provide different capacity building services. For instance, in 2013, in order to increase the annual food deficit of Ethiopia, the Chinese South-South Cooperation team sent thirty experts to improve the limited technology, resource management and agricultural development (Food and Agriculture Organizations of the United Nations, 2015). The project brought outstanding results on the production of livestock, crop and other agricultural products. According to the Ministry of Agriculture of China (2016), the country established the Chinese Agricultural Demonstration Center Program in Africa in 2006. However, some respondents state that Chinese enterprises prefer to hire Chinese citizens instead of training local one in areas which need highly skilled personnel.

\subsection{Challenges to Ethio-China Cooperation}

Despite Ethio-China economic cooperation is growing from time to time, there are some challenges that should be addressed enhance the cooperation and become more effective. The study indicate that the challenges that mainly arise from the Ethiopian side can be summarized into lack of competitive industries and institutional capacity.

As stated in the literature (Reith \& Boltz, 2011) and expressed by the participants, many feel that Ethiopia is gaining less from the Ethio-China cooperation. This is mainly due the less and agriculture-based export of Ethiopia to China. Therefore, the difference in the overall development of Ethiopia and China including economic, technological and industrial growth is affecting the win-win situation between the countries. It could be said that China is trying to compensate Ethiopia through different aid and loan programs. Referring to this issue, Kewser, a respondent stated:

The main challenge to Ethio-China cooperation could be Ethiopia's inability to produce competitive and sufficient amount of products that can be exported to China. This is because Ethiopia lacks strong economic base to build competitive industries and make the cooperation into win-win economic relationship.

Not completely different from the above argument, another respondent, Thomas, also said that Chinese technologies are challenging the domestic products even at home. Thomas explained:

Using their technological and capital advantage, Chinese exports and investment are undermining domestic products both for home use and export. The main challenges are lack of technology, infrastructure and awareness of Ethiopian investors in of producing high quality and quantity of export goods. There is also limited awareness on the management of the foreign investment policy and the complexity of the supply chain from the very beginning of production stage to the end of supply of products.

The previous excerpts show that similar to many developing countries, Ethiopia lacks strong technological and industrial developments to produce finished goods that could compete with the Chinese products. This is basically the main problem with the trade deficit in Ethiopia. It is for this reason many argued that South-South Cooperation needs a competitive socio-economic development for comparatively satisfactory win-win strategy between the partners.

As many of the respondents indicated, Ethiopia lacks well trained professionals to enable less bureaucratic and on time facilitation of services. Furthermore, Chinese companies especially at the construction and manufacturing sectors lack trained Ethiopian professionals to enable skill and technology transfer (World Bank, 2012). This could be the reason that Chinese companies prefer to hire lead professionals from China. However, some of the respondents argue that Chinese enterprises are not willing to transfer technology to their Ethiopian counterparts. 


\section{Conclusion and Implications}

\subsection{Conclusions}

Ethio-China economic cooperation is historical and strategic based on mutual friendship and non-interference principle of South-South Cooperation and their respective foreign policies. Since the initiation of official diplomatic relationship in 1970, Ethiopia and China has signed different agreements to strengthen their economic cooperation in general and increase trade in particular. Despite the trade imbalance and some challenges, Ethiopia and China are engaging through South-South Cooperation in a very constructive way. Trade between the two countries is surging and investment is increasing. Moreover, the result of the gravity model indicated that Chinese population and distance between Ethiopia and China is affecting negatively the trade between the two countries.

Chinese investors in Ethiopia are creating thousands of jobs both at lower and upper positions, while providing various training to their employees. Moreover, the cooperation is helping to uplift Ethiopia's economic development and meet its objective of becoming a middle income country by 2025 . The government of China is also providing various capacity development programs as well as politically free aid and loan to Ethiopia, unlike the experiences with Western countries.

Furthermore, the result of the questionnaire showed that Ethiopia has many things to learn from China including the strategy of developing a large country and building strong trade and investment in the world within three decades. All the ways that China travelled in advancing its technology, economy and especially in alleviating poverty are great lessons for Ethiopia. This could also be done not only at governmental level, but also at institutional and grassroots levels. Different institutions especially these that are jointly owned by Ethiopians and Chinese are mainly the source of labor, management and other relevant synergies between Ethiopian and Chinese institutions and citizens.

The study indicated that there are some challenges that need to be addressed to further strengthen the Ethio-China cooperation. Ethiopia lacks strong and big industries to export finished goods to China which is aggravating the trade deficit with China. The country only depends on agricultural and raw products while China exports heavy machinery to Ethiopia. Moreover, there is lack of skilled human resources to deliver efficient services and tap the investment projects with regard to knowledge transfer to Ethiopians.

Due to financial and time limitations, the research is not able to include the voices of various stakeholders from both countries. It focuses on trade and investment relations between the two countries mainly from the Ethiopian side. Hence, the Ethio-China economic cooperation from the Chinese side and the influence of China's trade and investment should be further studied.

\subsection{Implications}

The study implies that South-South Cooperation in general and trade and investment in particular increases countries economic growth and development by providing different opportunities such as employment, capacity development and FDI. Furthermore, the level of skilled human resources affects the transfer of knowledge and technology between Southern Countries. However, South-South Cooperation becomes more beneficial and valuable when the partner countries share similar socio-economic conditions. In this sense, Ethiopia needs to develop big and strong industries not only to compete with Chinese industries, but also to strengthen its export capacity. The implication of the study for other developing countries is that South-South Cooperation needs a very comprehensive technical cooperation supported by the partner governments' political relationship. With the facilitation of both governments, trade and investment could soar to its highest level benefiting the countries. 


\section{References}

Addis Fortune. (2013, February 18). China positive on Ethiopian investment despite some concerns. Retrieved from http://addisfortune.net/columns/china-positive-on-ethiopian-investment-despite-some-concerns/

Agarwal, M. (2013). South-South Economic Cooperation: Emerging trends and future challenges (Background Research Paper). Retrieved from http://www.post2015hlp.org/wp-content/uploads/2013/05/Agarwal_South-South-Economic-Cooperatio n-Emerging-Trends-and-Future-Challenges_FINALFINAL.pdf

Assefa, H., Bienen, D., \& Ciuriak, D. (2013). Ethiopia's investment prospects: A sectoral overview. African Review of Economics and Finance, 4(2), 203-246.

Babu, S. C., \& Sengupta, D. (2006). Capacity development as a research domain: Frameworks, approaches, and analytics (ISNAR Discussion Paper 9). Washington DC: International Food Policy Research Institute.

Bilal, S. (2012). The rise of south-south relations: Development partnerships reconsidered'. Brussels, European Centre for Development Policy Management. Retrieved from http://www.vvob.be/vvob/files/publicaties/20120530_ontwikkelingsdebat_bilal_05-12_south-south_par tnership.pdf

Bryman, A. (2008). Social research methods (3rd ed.). New York: Oxford University Press.

Caporale, G. M., Sova, A., \& Sova, R. (2015). Trade flows and trade specialisation: The case of China. DIW Berlin. Retrieved from http://www.diw.de/discussionpapers

Dargin, J. (2013). The rise of the global South: Philosophical, geopolitical and economic trends of the 21st century (eds.). Singapore: World Scientific Publishing Co. https://doi.org/10.1142/8430

Deardorff, A. (1998). Determinants of bilateral trade: Does gravity work in a neoclassical world. In Frankel, J. A. (Ed). The Regionalization of the world Economy (pp. 7-32). University of Chicago Press. Retrieved from http://www.nber.org/chapters/c7818.pdf

Ethiopian Chamber of Commerce and Sectorial Associations (ECCSA). (2012). A brief overview of the bilateral trade relationship between Ethiopia and China. Retrieved from www.ethiopianchamber.com/Data/Sites/1/downloadables/b2b.../china-profile.docx

Food and Agriculture Organizations of the United Nations. (2015). China-Ethiopia South-South Cooperation project: Ethiopian farmers see increase in net income. Retrieve from http://www.fao.org/3/a-i4700e/i4700e04.pdf

Forum on China-Africa Cooperation. (FOCAC). (2011). The largest private shoe-manufacturing enterprise in Dongguan makes investment in Ethiopia. FOCAC, Addis Ababa. Retrieved from http://www.fmprc.gov.cn/zflt/chn/zfgx/zfgxjmhz/t886616.htm.

Geda, A. (2008). Scoping study on the Chinese relation with sub Saharan Africa: The case of Ethiopia. Nairobi: African Economic Research Consortium.

Ghebreyesus, T. A. \& Yi, W. (2014, December 01). Ethiopia-China relations: An excellent model for South-South cooperation. Retrieved from http://www.mfa.gov.et/PressMore.php?pg=60

Japan International Cooperation Agency. (2005). Thematic guidelines on South-South Cooperation. Retrieved from http://gwweb.jica.go.jp/km/FSubject2101.nsf/03a114c1448e2ca449256f2b003e6f57/a86789dc7894cdd 0492579d4002b9963/\$FILE/JICA_TG_South-SouthCooperation_En_2005.pdf

Labuschagne, A. (2003). Qualitative research: Airy fairy or fundamental? The Qualitative Report, 8(1), 100-103.

Lei, W. (2015, November 12). Rediscovering Africa ep4: Huajian Group boosts Ethiopian manufacturing sector. Retrieved from http://english.cntv.cn/2015/11/12/VIDE1447325907987305.shtml

McNabb, D. E. (2008). Research methods in Public Administration and Nonprofit Management: Quantitative and qualitative approaches (2nd ed.). New Delhi: PHI Learning Private Limited.

Ministry of Agriculture of China. (2016). Agricultural ties grow stronger. Retrieved from http://english.agri.gov.cn/news/dqnf/201601/t20160111_164522.htm

Ministry of Foreign Affairs of China. (2006, October 10). Ethiopia. Retrieved from http://www.china.org.cn/english/features/focac/183534.htm 
Developing south-south cooperation: The case of Ethio-China economic relationship

Ministry of Foreign Affairs of Ethiopia. (2010). Ethiopia-China (PRC) relation. Retrieved from http://www.mfa.gov.et/BilateralMore.php?pg=9

OECD. (2011). Unlocking the potential of South-South Cooperation: Policy recommendations from the Task Team on South-South Cooperation. Retrieved from http://www.oecd.org/dac/effectiveness/TT-SSC\%20Policy\%20Recommendations.pdf

People's Daily Online. (2011, November 17). Ethiopia, China sign agreement on trade, economic cooperation. Retrieved from http://en.people.cn/90883/7647622.html

Reith, S., \& Boltz, M. (2011). The East African community: Regional integration between aspiration and reality. Kas International Reports.

Rosseel, P., De Corte, E., Blommaert, J., \& Verniers, E. (2009). Approaches to North-South, South-South and North-South-South Collaboration: A policy document. Catholic University of Leuven. Retrieved from http://www.mcr-bvba.be/documents/approaches-tonorth-south-s-s-and-n-s-s-collaboration-a-policy-doc ument-for-the-vlir.pdf

Schreurs, M. (2013). Ethiopia's economy grows with Chinese investment. Retrieved from http://globalriskinsights.com/2013/11/ethiopias-economy-grows-with-chinese-investment

Sen, A. (2003). Development as capacity expansion. In Sakiko Fukuda-Parr and A.K. Shiva Kumar (eds.), Readings in human development (pp. 3-16). New Delhi and New York: Oxford University Press

Task Team on South-South Cooperation. (2011). Unlocking the potential for South-South Cooperation. Retrieved from http://www.oecd.org/dac/effectiveness/TT-SSC\%20Policy\%20Recommendations.pdf

The Observatory of economic complexity. (2014). Ethiopia. http://atlas.media.mit.edu/en/profile/country/eth/

Trading Economics. (2016). Balance of trade. Retrieved from http://www.tradingeconomics.com/

Ugwuja, A. A., Ubaku, K. C.,Obiakor, N.J., \& Ibekilo, B. (2014). South - South Cooperation and the prospects of a new international economic order: An insight into the India Brazil-South Africa (IBSA) Dialogue Forum. International Journal of Humanities Social Sciences and Education (IJHSSE), 1(8), 171-182.

United Nations. (2003, March 17). Technical cooperation among developing countries. Retrieved from http://ssc.undp.org/content/dam/ssc/documents/Key\%20Policy\%20Documents/SSC\%2017_3E.pdf.

United Nations. (2012, April 12). South-South Cooperation for development. Retrieved from http://www.undp.org/content/dam/undp/library/Poverty\%20Reduction/Development\%20Cooperation\% 20and\%20Finance/SSC_FAQ\%20v1.pdf

United Nations Population Fund. (2011). Policies \& procedure manual: South-South Cooperation Strategy. Retrieved from http://www.unfpa.org/sites/default/files/admin-resource/TD_South-South\%20Cooperation\%20Strategy. pdf

Vaes, S., \& Huyse, H. (2013). New voices on South-South Cooperation between emerging powers and Africa: African civil society perspectives. Belgium: HIVA-KU Leuven.

Wei, W. (2010). China-Africa Cooperation pushing Africa's Economic Development. FOCAC, Addis Ababa. Retrieved from http://www.focac.org/eng/xsjl/xzhd/t712157.htm

Wiersma, W., \& Jurs, S. G. (2004). Research methods in education: An introduction (8th ed.). China: Pearson Education.

World Bank. (2012). Chinese FDI in Ethiopia: A World Bank survey. Retrieved from http://www-wds.worldbank.org/external/default/WDSContentServer/WDSP/IB/2012/12/14/000386194 20121214024800/Rendered/PDF/NonAsciiFileName0.pdf

World Bank. (2014a). Country profile: Ethiopia. Retrieved from http://data.worldbank.org/

World Bank. (2014b). World integrated trade solution. Retrieved from http://wits.worldbank.org/CountryProfile/en/Country/ETH/Year/2014/Summary

Zizhu, Z. (2015, November 18). Inside the Chinese factory in Ethiopia where Ivanka Trump places her shoe orders. Retrieved from http://china-africa-reporting.co.za/2017/01/inside-the-chinese-factory-in-ethiopia-where-ivanka-trumpplaces-her-shoe-orders/ 
Damtew, R. Y., \& Tsegay, S. M. 